\title{
Neotropical Piper species: Are they all hermaphroditic?
}

\author{
Adriano Valentin-Silva ${ }^{\mathrm{a}}$, Marco Antonio Batalha ${ }^{\mathrm{b}}$, Elza Guimarães ${ }^{\mathrm{c}, *}$

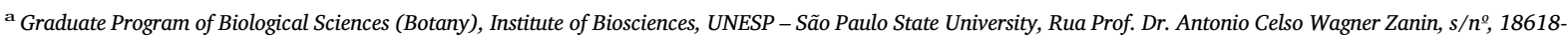 \\ 689, Botucatu, SP, Brazil \\ ${ }^{\mathbf{b}}$ Department of Botany, Federal University of São Carlos, PO Box 676, 13565-905, São Carlos, São Paulo, Brazil \\ ${ }^{\mathrm{c}}$ Department of Botany, Institute of Biosciences, UNESP - São Paulo State University, Rua Prof. Dr. Antonio Celso Wagner Zanin, s/ $n^{\circ}$, 18618-689, Botucatu, SP, Brazil
}

\section{A R T I C L E I N F O}

Edited by Dr. Favio Gonzalez

Keywords:

Andromonoecy

Cryptic unisexuality

Floral functionality

Sexual dimorphism

\begin{abstract}
A B S T R A C T
Sexual expression has been used as a distinctive character among the clades of the genus Piper. Unisexual flowers are described for Paleotropical species, which are usually dioecious, whereas bisexual flowers are associated with Neotropical species, considered as hermaphroditic. However, the registration of an andromonoecious species in the Neotropics, associated with the morphological similarity of Piper flowers, suggests that the presence of functionally unisexual flowers may be more common than the one recorded so far. To investigate this possibility, we determined the sexual expression of 17 Neotropical Piper species, focusing on the functionality of the flowers along the anthesis in individuals of a semideciduous seasonal forest. We found 13 hermaphroditic species, one andromonoecious and three with variable combinations of hermaphroditic, andromonoecious and male individuals. The staminate flowers presented cryptic unisexuality. Species with more than one floral type presented sexual dimorphism, differing in length of their inflorescences and pistils of flowers. Although hermaphroditism is the predominant sexual expression among Neotropical Piper species, we observed variations of this expression in almost $25 \%$ of the species studied here, indicating that the unisexual flowers may have evolved independently in different clades of Neotropical and Paleotropical species.
\end{abstract}

\section{Introduction}

Most of the angiosperms species are hermaphroditic (Yampolsky and Yampolsky, 1922; Barrett and Hough, 2013), but there are other types of sexual expressions due to the presence of different floral types in one or more individuals of a species (Sakai and Weller, 1999). The determination of sexual expression is based on floral morphology, however, it is also necessary to analyze the functionality of the flowers because morphologically hermaphroditic flowers may present nonfunctional androecium or gynoecium (Mayer and Charlesworth, 1991). Thus, unusual sexual expressions can be detected as cryptic dioecy (Mayer and Charlesworth, 1991) and functional androdioecy (Liston et al., 1990; Zhou et al., 2016).

Piper L. has about 2000 species with Pantropical distribution (Quijano-Abril et al., 2006) and probably originated in the Neotropics (Smith et al., 2008), the region with the greatest species richness (Jaramillo and Manos, 2001). In Brazil, it is represented by 290 species (Guimarães et al., 2015) and the Tropical Atlantic Forest is one of the centers of endemism, with about 150 species (Jaramillo and Manos, 2001; Quijano-Abril et al., 2006).

The tiny flowers of Piper species are, at first sight, morphologically similar: perianthless, protected by a bract, with 1-10 stamens and 3-4 carpels (Yuncker, 1972, 1973; Jaramillo and Manos, 2001). Despite this, these species present a great diversity related to the floral bract morphology, the floral development and the dynamics of stigmatic exposure and pollen release (Tucker, 1982; Jaramillo et al., 2008; Valentin-Silva et al., 2018). Phylogenetic studies have shown that the genus is composed of three clades that differ in the geographic distribution and sexual expression of the species (Jaramillo and Manos, 2001; Jaramillo et al., 2008). Bisexual flowers and, therefore, hermaphroditic species have been described for the Neotropics, whereas, in the Paleotropics (Asia and South Pacific), unisexual flowers and dioecious species predominate (Wanke et al., 2007; Jaramillo et al., 2008). Despite this difference, it is not clear which sexual expression is a synapomorphy of these clades (Jaramillo and Manos, 2001).

Although hermaphroditism is considered the only sexual expression of Neotropical species, Figueiredo and Sazima (2000) showed that there may be variation, such as the andromonoecy observed in Piper arboreum Aubl. This species has bisexual flowers and functionally staminate flowers in the same plant, but the occurrence of sexual dimorphism, a common feature in species with more than one floral type (Eckhart, 1999), was not described for this species.

\footnotetext{
* Corresponding author.

E-mail addresses: adrianovalentin86@gmail.com (A. Valentin-Silva), marcobat@fastmail.fm (M.A. Batalha), elza.guimaraes@unesp.br, elzaguimaraes.bot@gmail.com (E. Guimarães).
} 
The evaluation of floral characters in Piper herbarium specimens is difficult (Jaramillo and Manos, 2001), since it can mask small morphological variations in flowers and presents limitations in relation to the temporal sequence of anthesis events. Consequently, the presence of functionally unisexual flowers may be more common than the one recorded so far. Thus, we aimed to analyze sexual expression in Neotropical Piper species, focusing on the sexuality of flowers and plants, to test the occurrence of sexual expressions distinct from hermaphroditism. In addition, we tested whether the non-hermaphroditic species had sexual dimorphism between different floral types.

\section{Methods}

\subsection{Study area and species}

We carried out this study from April 2014 to March 2016 at the 'Station of Research, Environmental Training and Education Mata do Paraíso' (hereafter, Mata do Paraíso), located in Viçosa $\left(20^{\circ} 47^{\prime}-48^{\prime} \mathrm{S}\right.$, $42^{\circ} 50^{\prime}-52^{\prime} \mathrm{W}$ ), Minas Gerais State, southeastern Brazil. This reserve has 194 ha of seasonal semideciduous montane forest (Veloso et al., 1991) and altitudes varying from 690 to $870 \mathrm{~m}$.

At the study area, we recorded 17 Piper species, which belong to different clades of the genus (Table 1). To sample the plants, we used $5 \mathrm{~km}$ of previously established transects to mark individuals to be studied. As it was necessary to have adult individuals (at the reproductive stage), we used as inclusion criterion the presence of reproductive structures (inflorescences with floral buds, flowers or fruits) or marks (scars) on the branches that indicate previous reproductive episodes (Valentin-Silva and Vieira, 2015). We deposited voucher specimens in the BOTU Herbarium (Table 1).

\subsection{Sexual expression}

We evaluated the floral morphology of all species to test whether there were variations in the androecium and gynoecium that could indicate the presence of functionally unisexual flowers. So, we collected inflorescences, which were analyzed either fresh or fixed (stored in $70 \%$ ethanol), with a hand lens (60X increase) or under a stereomicroscope. Additionally, we observed the functionality of flowers throughout the anthesis. We randomly sampled three individuals per species, from the ones initially marked (Table 1) and followed, in all inflorescences, the events occurring during flower anthesis until their senescence to assign the sex of the flowers. Then, we evaluated the distribution of the floral types observed in the individuals of each species to assign the sex of the plants.

In species in which we identified in field the presence of more than one floral type, we analyzed vouchers to observe the presence of these floral types in other populations. The presence of more than one floral type in populations other than the studied in Viçosa, indicates that this floral dimorphism is a characteristic of the species. The presence of staminate flowers in vouchers was corroborated when we observed inflorescences with flowers at anthesis, which were releasing pollen, but whose gynoecium was atrophied, with stigmas below the anthers (all bisexual flowers of studied species showed incomplete protogyny; Valentin-Silva, 2017).

To exemplify the floral types observed, we collected samples of inflorescences, fixed in FAA (formaldehyde, acetic acid and ethanol $50 \%, 1: 1: 18 \mathrm{v} / \mathrm{v} / \mathrm{v}$ ) for $48 \mathrm{~h}$ and stored in $70 \%$ ethanol (Johansen, 1940). Thereafter, we dehydrated samples in an ethanol series, subjected to critical-point drying using $\mathrm{CO}_{2}$ and metal deposition with gold (Robards, 1978). We examined and captured images in a scanning electron microscope (model Quanta 200, Fei Company, Hillsboro, OR, USA).

In species with more than one floral type, we analyzed the length of the inflorescences composed of each floral type, the length of the pistil, the number of pollen grains produced by anther and the pollen viability in each floral type to test whether there was sexual dimorphism. We measured the length of inflorescences with a digital caliper or tape measure in 10 inflorescences ( $\mathrm{n}=10$ individuals/floral type/species). To measure the length of the pistil, we photographed it in a stereomicroscopic coupled with a digital camera. We processed images in the program LAS 3.8, in which we did measurements in 10 flowers $(n=10$ individuals/floral type/species).

We counted the number of pollen grains per anther, using a method adapted from Roulston (2005). In a tube, we put an indehiscent anther, macerated in $0.5 \mathrm{~mL}$ of distilled water and homogenized the sample in a vortex shaker for $30 \mathrm{~s}$. We removed an aliquot of $0.01 \mathrm{~mL}$ and counted the number of pollen grains in a sedgwick rafter, under a light microscope. We extrapolated the value found in the aliquot for the initial sample. We counted the number of pollen grains in 10 anthers $(n=10$ individuals/floral type/species).

We tested pollen viability with acetic carmine (Radford et al., 1974) in 10 inflorescences ( $\mathrm{n}=10$ individuals/floral type/species). To do this, we macerated five anthers of different flowers of the same inflorescence in a drop of acetic carmine. In each slide, we counted 200 pollen grains under a light microscope, separating them into viable and

Table 1

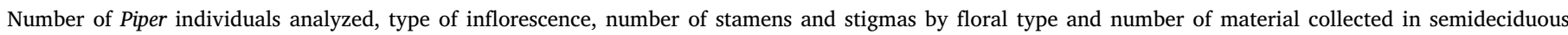
seasonal forest, Viçosa, southeastern Brazil.

\begin{tabular}{|c|c|c|c|c|c|c|c|}
\hline \multirow[t]{2}{*}{ Species } & \multirow[t]{2}{*}{ Clade } & \multirow[t]{2}{*}{ Individuals } & \multirow[t]{2}{*}{ Inflorescence } & \multicolumn{2}{|c|}{ Bisexual flowers } & \multirow{2}{*}{$\begin{array}{l}\text { Unisexual flowers } \\
\text { Stamens }\end{array}$} & \multirow{2}{*}{$\begin{array}{l}\text { Voucher } \\
\text { (BOTU) }\end{array}$} \\
\hline & & & & Stamens & Stigmas & & \\
\hline Piper aduncum L. & Radula & 13 & spike & 4 & 3 & & 32,$180 ; 32,198$ \\
\hline P. amplum Kunth & Radula & 11 & spike & 6 & 3 & & 32,$187 ; 32,194$ \\
\hline P. anisum (Spreng.) Angely & Ottonia & 12 & raceme & 4 & 4 & & 32,188 \\
\hline P. arboreum Aubl. & Macrostachys & 10 & spike & 4 & $3-4$ & 4 & 32,181 \\
\hline P. caldense C. DC. & Peltobryon & 15 & spike & 4 & 3 & 4 & 32,$195 ; 32,201$ \\
\hline P. cernuum Vell. & Macrostachys & 14 & spike & 4 & $3-4$ & 4 & 32,$172 ; 32,200$ \\
\hline P. chimonanthifolium Kunth & Radula & 15 & spike & 4 & 3 & 4 & 32,$196 ; 32,199$ \\
\hline P. corcovadensis (Miq.) C. DC. & Ottonia & 15 & raceme & 4 & 4 & & 32,191 \\
\hline P. crassinervium Kunth & Radula & 11 & spike & 4 & 3 & & 32,$175 ; 32,177$ \\
\hline P. gaudichaudianum Kunth & Radula & 12 & spike & 4 & 3 & & 32,$173 ; 32,183$ \\
\hline P. hispidum Sw. & Radula & 15 & spike & 4 & 3 & & 32,$174 ; 32,184$ \\
\hline P. lucaeanum Kunth & Schilleria & 15 & spike & 3 & 3 & & 32,$182 ; 32,193$ \\
\hline P. malacophyllum (C. Presl) C. DC. & Radula & 10 & spike & 4 & 3 & & 32,$178 ; 32,185$ \\
\hline P. mollicomum Kunth & Radula & 10 & spike & 4 & 3 & & 32,$179 ; 32,190$ \\
\hline P. pubisubmarginalum Yunck. & Schilleria & 15 & spike & 3 & 3 & & 32,192 \\
\hline P. umbellatum $\mathrm{L}$. & Pothomorphe & 15 & umbel of spikes & 2 & 3 & & 32,176 \\
\hline P. vicosanum Yunck. & Radula & 15 & spike & 4 & 3 & & 32,$189 ; 32,197$ \\
\hline
\end{tabular}



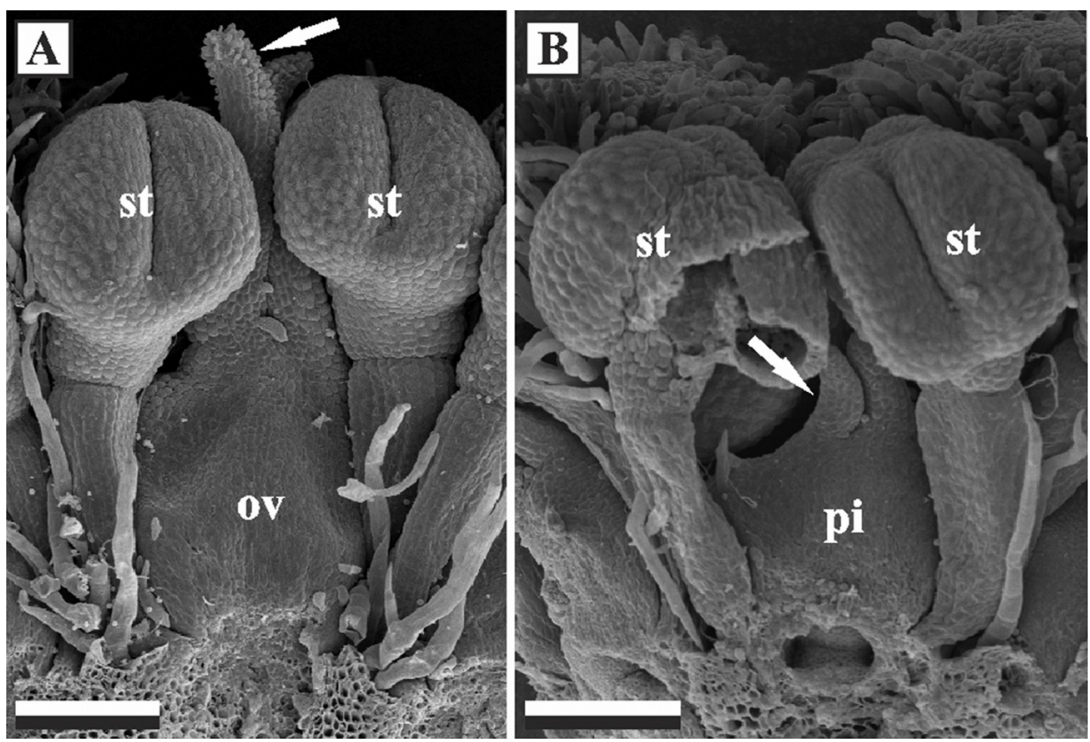

Fig. 1. Floral types observed in Piper species in a semideciduous seasonal forest, in Viçosa, southeastern Brazil. A: bisexual flower (note the stigmas between the anthers, arrow). B: functionally male flower (note the atrophied stigmas, arrow) in P. chimonanthifolium. ov $=$ ovary, pi $=$ pistillode, st $=$ stamen. Scale bars: $200 \mu \mathrm{m}$.

non-viable based on their color, shape and size (Kearns and Inouye, 1993).

We compared inflorescence length, pistil length, number of pollen grains per anther and pollen viability in species with more than one floral type by means comparison test (ANOVA for length of inflorescences in $P$. chimonanthifolium and $t$-test for the other species and variables), using R (R Core Team, 2016). The pollen viability data were transformed (arc-sine) to meet the normality requirement.

\section{Results}

Of the 17 studied species, 13 had only bisexual flowers (Table 1, Fig. 1A), characterizing the sexual expression of these species as hermaphroditic (Fig. 2A). The other four species presented two floral types, bisexual and functionally unisexual male flowers (hereafter, staminate) (Table 1). The staminate flowers had a reduced and nonfunctional pistil (pistillode, Fig. 1B) and senesced after pollen release. We corroborated the presence of staminate flowers in $P$. arboreum, $P$. caldense, $P$. cernuum and $P$. chimonathifolium in vouchers of specimens collected in different regions of Brazil (Table 2, Appendix A).

Piper cernuum presented two floral types (bisexual and staminate flowers, Table 1) and both types were observed in the same individual.

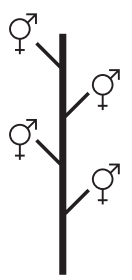

B

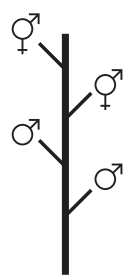

D

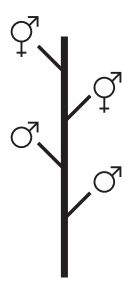

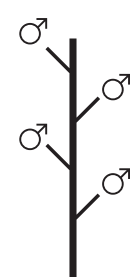

E

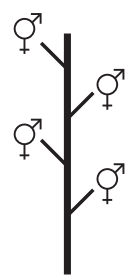

Table 2

Number of exsicates of Piper species analyzed to verify the presence of staminate flowers.

\begin{tabular}{lccc}
\hline \multirow{2}{*}{ Species } & \multicolumn{3}{c}{ Exsicates } \\
\cline { 2 - 4 } & Total & With bisexual flowers & With staminate flowers \\
\hline Piper arboreum & 871 & 186 & 58 \\
$P$. caldense & 274 & 87 & 23 \\
$P$. cernumm & 257 & 25 & 6 \\
$P$. chimonanthifolium & 79 & 25 & 7 \\
\end{tabular}

Each inflorescence presented only one floral type, that is, there were spikes with bisexual flowers and spikes with staminate flowers (five plants analyzed; Fig. 2B), characterizing its sexual expression as andromonoecious.

Piper arboreum and $P$. caldense also presented these two floral types (Table 1); however, the distribution varied in individuals. In $P$. arboreum, we observed two individuals only with spikes with bisexual flowers and three individuals with the two floral types (spikes with bisexual flowers and spikes with staminate flowers). Therefore, there were hermaphroditic individuals and andromonoecious individuals

C

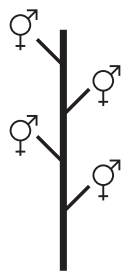

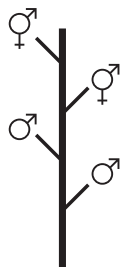

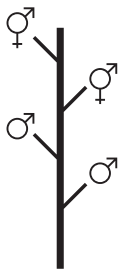

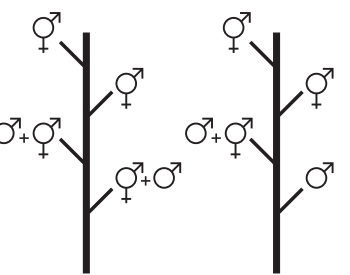

Fig. 2. Scheme of sexual expressions observed in Piper species in a semideciduous seasonal forest, in Viçosa, southeastern Brazil. A: hermaphroditic species. B: andromonoecious species (P. cernuum). C: species with hermaphroditic and andromonoecious individuals $(P$. arboreum). D: species with andromonoecious and male individuals ( $P$. caldense). E: species with hermaphroditic and andromonoecious individuals and mixed spikes ( $P$. chimonanthifolium). Each lateral branch with symbol represents an inflorescence. 
(Fig. 2C). Piper caldense also presented two types of individuals: 13 with spikes with bisexual flowers and spikes with staminate flowers and two with spikes with staminate flowers. Thus, there were andromonoecious individuals and male individuals in the analyzed population (Fig. 2D).

Piper chimonanthifolium, in addition to having both floral types (Table 1), presented variation in the distribution of these types in inflorescences and plants. We observed three types of inflorescences: spikes with bisexual flowers, spikes with staminate flowers and spikes with the two floral types (mixed spikes). The mixed spikes presented bisexual flowers in the basal portion and staminate flowers in the apical portion; the proportion of floral types varied among inflorescences, but generally bisexual flowers prevailed. Bisexual flowers of mixed spikes formed fruits, whereas staminate flowers senesced after pollen release and the portion of the spike with these flowers was usually eliminated. Of the 15 individuals analyzed, five presented only spikes with bisexual flowers, two had spikes with bisexual flowers and spikes with staminate flowers, two had spikes with bisexual flowers and mixed spikes and six had all three types of spikes. Therefore, there were hermaphroditic individuals and andromonoecious individuals (Fig. 2E).

These species presented difference between the floral types only in the length of the inflorescences and the pistil (Table 3). In the four species, the spikes with bisexual flowers were longer than the spikes with staminate flowers. In the case of Piper chimonanthifolium, the mixed spikes had an intermediate length between the spikes with bisexual flowers and those with staminate flowers (Table 3 ). The pistil of the bisexual flowers was longer than in the staminate flowers in the four species (Table 3 ).

\section{Discussion}

Bisexual flowers, present in all 17 studied species, are commonly observed in Neotropical Piper species, but the staminate flowers, observed in P. arboreum (Figueiredo and Sazima, 2000), P. caldense, $P$. cernuum and $P$. chimonanthifolium, are rare in this clade, since Piper species with unisexual flowers were referred only to Asia and the South Pacific (Jaramillo et al., 2008). The staminate flowers of the Neotropical species present cryptic unisexuality sensu Mayer and Charlesworth (1991), because they are morphologically bisexual with unisexual function, a fact that may have contributed to the interpretation of hermaphroditism as a universal characteristic of Neotropical species. The inflorescences of most species here examined are composed only of bisexual or staminate flowers. However, Piper chimonanthifolium presented a distinct composition: in addition to inflorescences with bisexual flowers and inflorescences with staminate flowers, it has mixed inflorescences, with two floral types, characteristic which had not been described for Neotropical species of the genus. A similar result was observed in Piper pedicellatum C. DC., Paleotropical and dioecious species, which presented some mixed inflorescences composed of bisexual flowers and pistillate flowers, as well as female inflorescences (Lei and Liang, 1998). These results reinforce the need to combine analysis of morphology with flower functionality throughout anthesis.

Hermaphroditism, the sexual expression observed in most of the analyzed species, is considered one of the characteristics which define the Neotropical Piper species clade (Jaramillo et al., 2008). It was also observed andromonoecy in P. cernuum, another monomorphic sexual expression, and dimorphic sexual expressions in the species $P$. arboreum, $P$. caldense and $P$. chimonanthifolium. These results differed from those reported by Jaramillo and Manos (2001), who pointed to sexual expression as a distinctive characteristic between Paleotropical (dioecious or monoecious) and Neotropical (hermaphroditic) species.

The presence of two types of individuals with different floral types (andromonoecious and hermaphroditic in $P$. arboreum and P. chimonanthifolium and andromonoecious and male in $P$. caldense) characterized the populations of these species as dimorphic sensu Sakai and Weller (1999). Piper arboreum was classified as andromonoecious by

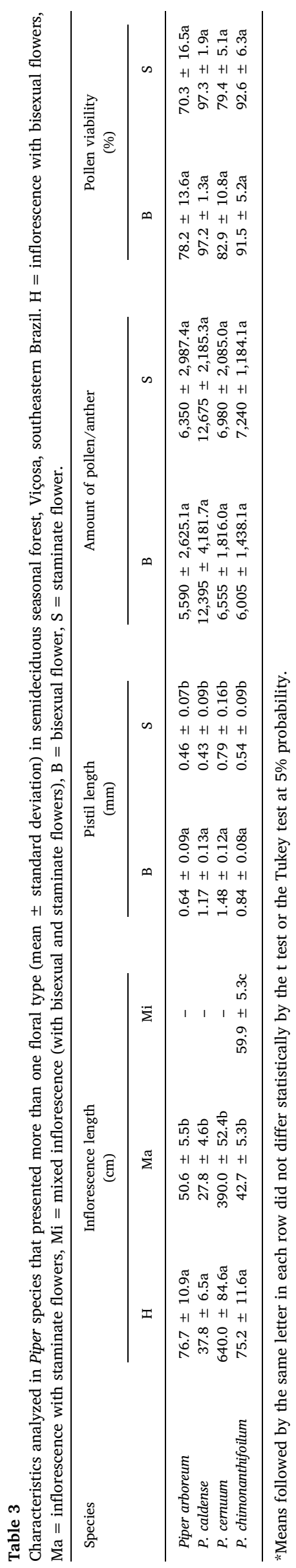


Figueiredo and Sazima (2000), but the population studied by these authors presented similar sexual expression to that observed in the present study (andromonoecious and hermaphroditic individuals; Figueiredo, 1997), varying only the proportion of the types of individuals in the population. Sexual expression varies over time or space (Sakai and Weller, 1999), which may explain the differences observed between the populations of this species. It is possible that the analyzed populations of $P$. arboreum and $P$. chimonanthifolium are in transition from hermaphroditism to andromonoecy, which may be a stable sexual expression or represent an intermediate step for ginodioecy or dioecy (Webb, 1999).

Piper caldense can be considered as androdioecious sensu Sakai and Weller (1999), because it has individuals with staminate flowers and individuals with hermaphroditic function (andromonoecious individuals, that is, with bisexual and staminate flowers in the same plant). Androdioecy is rare in angiosperms (Yampolsky and Yampolsky, 1922; Pannell, 2002) and the study of other populations may confirm this possibility. Although androdioecy generally evolves from dioecy (Charlesworth, 1984; Pannell, 2002), it can also derives from hermaphroditism if the species is self-incompatible (Webb, 1999), as is the case of $P$. caldense (Valentin-Silva, 2017). Androdioecy with hermaphroditic ancestral was observed in Sagittaria lancifolia (Alismataceae; Muenchow, 1998; Pannell, 2002).

The difference in the length of the pistil and also in the size of the spikes with bisexual flowers and with staminate flowers pointed out that these species present sexual dimorphism, respectively, in a primary and secondary sexual character (Sakai and Weller, 1999). Thus, the length of the inflorescences can be a diagnostic character to separate the types of individuals within a species. Differences among floral types in size of floral parts, number of flowers in inflorescence and production of floral resources (nectar) have already been recorded in different angiosperms species (see Eckhart, 1999; Barrett and Hough, 2013). However, we observed no difference in the quantity and viability of pollen grains, the only floral resource available to Piper pollinators (Figueiredo and Sazima, 2000; Valentin-Silva, 2017). On the other hand, the presence of viable pollen in the staminate flowers and in a quantity similar to that of bisexual flowers confirms their male function.

\section{Conclusion}

Although hermaphroditism is the predominant sexual expression among Neotropical Piper species, variations of this expression may be more common than initially believed, considering that we observed them in almost $25 \%$ of the species studied here. The presence of staminate flowers increases the export of pollen in these plants and may be related to the attraction of pollinators (Primack and Lloyd, 1980; O'Brien, 1994), suggesting a possible advantage in their sexual reproduction. In addition, the other sexual expressions found must be derived, since the genus Piper originated in the Neotropics (Smith et al., 2008), and most species of this region are hermaphroditic (Jaramillo and Manos, 2001; Jaramillo et al., 2008). These variations indicate that unisexual flowers may have evolved independently in different clades of Neotropical and Paleotropical species.

\section{Acknowledgements}

The authors thank the Coordination for the Improvement of Higher Education Personnel (Capes) and the National Council for Scientific and Technological Development (CNPq) for the scholarships for a Doctor's degree and research productivity (number 305912/2013-5) granted, respectively, to the first and second authors. We also thank the Electron Microscopy Center of São Paulo State University, Institute of Biosciences, the staff of the herbaria BOTU, RB and VIC for the support during the analysis of exsicates, and to the herbarium UB by the loan of exsicates. We are indebted to Elsie Franklin Guimarães and Micheline
Carvalho-Silva for their assistance in plant identification.

\section{Appendix A}

List of material examined in the herbaria BOTU, RB, UB and VIC in which we observed the presence of staminate flowers

Piper arboreum Aubl.

BRAZIL. BAHIA: Itaberaba, ARIE Serra de Orobó, serra da Gameleira, 21/IX/2005, D. Cardoso 793 (RB). ESPÍRITO SANTO: Alegre, propriedade do senhor Adalto, estrada sentido "ponte do baiano", 29/XI/2010, V.C. Manhães \& D.R. Couto 253 (RB); Ibitirama, propriedade particular (Alcindo Luis Mota Filho) a $5 \mathrm{~K} \mathrm{~m}$ da entrada de Ibitirama, 28/X/2012, T.B. Flores \& O.R. Campos 1649 (RB); Linhares, Reserva Natural Vale, estrada Roxinho, próximo ao aceiro Catelã, 08/ IV/2006, M.A. Pinho-Ferreira, L. Lorenzo, C.D.N. Rodrigues, R.A.G. Viani, V.C. Souza \& V.R. Scalon M625 (RB); idem, rio Bananal, mata ciliar, 25/V/2012, D.A. Folli 6863 (RB); Santa Leopoldina, 17/I/2008, L.A. Pereira, E.F. Guimarães, V.F. Mansano, F.L.R. Filardi \& G. Heiden 1553 (RB); Santa Teresa, estrada para Santa Leopoldina, em frente a plantação de eucalipto, 13/IX/2006, R. Marquete, N. Marquete, M.C. Valente \& J.C. Silva 3900 (RB). GOIÁS: Caldas Novas, córrego Bálsamo, 27/VII/1993, H. Santos, C. Soares, S. Cordovil, T.A.B. Dias, D.A. Neto, J.A. Silva \& V.S. Silva 161 (RB); Colinas do Sul, APA Pouso Alegre, estrada após Agropecuária Sarkis, entrada a 4,5 K m após a ponte da divisa Minaçú/Colinas do Sul, 02/IX/2005, M.L. Fonseca, R.C. Mendonça, F.C.A. Oliveira, S.A. Pequeno \& G.P. Araújo 5928 (RB); Mossâmedes, riacho na base da serra Dourada, 20/XII/2007, R.C. Forzza, R.F. Monteiro, M.M. Saavedra, R. Moura \& M.G. Avelar 4566 (RB); Niquelândia, fazenda Engenho, ca. $11 \mathrm{~K} \mathrm{~m}$ de Niquelândia/Dois Irmãos, 27/VI/1997, F.C.A. Oliveira, T.S. Filgueiras, M.L. Fonseca e A.J.V. Santos 774 (RB); Pirenópolis, beira de estrada ligando Pirenópolis a Cacalzinho, 25/VII/1992, A.F. Carvalho 66 (VIC). MINAS GERAIS: Governador Valadares, em praia de areia na margem do rio Doce, 23/XI/1941, M. Magalhães 784 (RB); Juiz de Fora, Reserva Biológica Poço das Antas, 05/I/1989, O. Moreira \& S. Borges 23422 (RB); Ouro Preto, Parque Estadual do Itacolomi, mata do Cibrão, 13/ III/2007, R.S. Araújo \& T.S. Coser s/n (VIC); Raul Soares, sítio córrego de Ubá, 03/VIII/1992, A.F. Carvalho 36 (RB); idem, 03/VIII/1992, A.F. Carvalho 37 (RB, VIC); Uberlândia, Estação Ecológica do Pangua, 19/ VI/1993, Feep 453 (RB); Viçosa, Recanto das Cigarras, 30/IV/1998, S.A.M. Alves 69 (RB, VIC). PARANÁ: Paranaguá, rodovia BR-277, trevo para Alexandra, 28/XI/2014, J.M. Silva \& J.T. Motta 8699 (RB). RIO DE JANEIRO: Cachoeiras de Macacu, street between Funchal and Guapiaçu, near REGUA, 02/VI/2009, K. Baker \& J. Wesenberg KB186 (RB); Duque de Caxias, III Distrito, Parque Natural Municipal de Taquara, trilha da cachoeira, 14/VI/2008, M.L.C. Valim, C.G. Campos, F.R. Souza, N. Silva, C.F. Silva, F.P. Uribbe \& C.E.S. Jascone 7 (RB); Itatiaia, Parque Nacional de Itatiaia, parte baixa, estrada para o Lago Azul, 28/X/2011, A. Lobão \& G.C. Lopes 1719 (RB); Maricá, Itaipuaçú, Parque Estadual da Serra da Tiririca, morro da Serrinha, antigo túnel ferroviário, 28/V/2014, G.A. Queiroz, D.N.S. Machado \& L.P.M. Moraes 147 (RB); Magé, 28/V/1983, R.R. Guedes 231 (RB); idem, Parque Nacional da Serra dos Órgãos, serra da Estrela, trilha entre Piabetá e Petrópolis, 20/I/2010, R.A. Engelmann \& O. Thier RE468 (RB); Mangaratiba, ilha de Marambaia, trilha para a praia da Armação, 08/ VI/2004, M. Nadruz \& M. Souza 1565 (RB); Nova Iguaçu, Reserva Biológica do Tinguá, 22/X/2002, L.C. Giordano, E.F. Guimarães, M.G. Bovini, S.J. Siva Neto \& W. Silva 2597 (RB); Paraíba do Sul, estrada de terra que liga BR-393 a Fazenda Roque dos Olhos d'Água e Fazenda Reunidas, 26/VII/2004, M. Carvalho-Silva, R. Marquete, C. Valente \& J.C. Silva 268 (RB); Parati, Laranjeiras, caminho para a praia do Sono, após a segunda porteira, fazenda Santa Maria, 04/VII/1992, L.C. Giordano, E.F. Guimarães, J. Caruso e J.C. Silva 1384 (RB); Petrópolis, Carangola, XII/1943, G.C. Goés \& D. Constantino 900 (RB); Rio de Janeiro, Copacabana, Área de Proteção Ambiental de Chacrinha, borda 
de mata na área de lazer do parque, 12/II/2004, L.J.T. Cardoso 102 (RB); idem, Jardim Botânico, mata de encosta do Parque Lage, trilha a direita da terceira queda d'água da cachoeira do Cabo de Aço, 11/IV/ 1995, L.C. Giordano, R. Furks, P. Botelho, R. Garcia \& F. Pinheiro 1893 (RB); idem, maciço da Tijuca, serra da Carioca, morro Mundo Novo, Botafogo, campus da Universidade Santa Úrsula, 14/I/1993, J.M.A. Braga \& T. Konno 221 (RB); idem, morro Mundo Novo, propriedade da U.S.U., 18/XII/1985, M. Gomes 21 (RB); idem, Pedra de Itaúna, 29/VII/ 1971, D. Sucre 7591 (RB); idem, Sumaré, 11/V/1955, E.F. Guimarães 16 (RB); Santa Maria Madalena, Alto do Imbé, estrada para Cruzeiro, terras do senhor Jorge, 24/X/2012, J.F.A. Baumgratz, M. Nadruz, B.C. Bandeira \& M. Souza 1251 (RB); idem, Parque Estadual do Desengano, Alto Imbé, picada para o Cruzeiro, 24/X/2012, B.C. Bandeira, J.F.A. Baumgratz, M. Nadruz \& M.C. Souza 141 (RB); Silva Jardim, Reserva Biológica Poço das Antas, mata secundária próxima ao plantio de Biovert - modelo tradicional, 15/IX/2001, C. Duarte 115 (RB); Teresópolis, Parque Nacional da Serra dos Órgãos, fazenda Mandioca, caminho para Poço da Esmeralda, 23/II/1984, L. Mantone \& E.F. Guimarães 71 (RB); Vassouras, Avelar, Horto Florestal de Pau Grande, 20/II/1978, M. Santos et al. 2 (RB); Visconde de Mauá, Parque Nacional de Itatiaia, ao lado do abrigo 2, 06/XII/2006, R. Marquete \& V.F. Mansano 4027 (RB). SÃO PAULO: Barra do Turvo, estrada de acesso a Barra do Turvo, 08/II/1995, H.F. Leitão-Filho, R.R. Rodrigues, A. Rozza, T. Sposito, K. Santos \& A.P. Vieira s/n (RB); Boa Esperança do Sul, margem da mata ciliar do rio Jacaré, 07/VII/1964, J.C. Gomes Jr. 2029 (UB); Caraguatatuba, 17/III/2006, A. Oliveira \& C. Purcell 2121 (RB); Colômbia, distrito de Laranjeiras, fazenda Perdizes, 27/VII/1994, W. Marcondes-Ferreira \& L.L. Venturi 947 (RB); Iguapé, Estação Ecológica Juréia-Itatins, serra da Juréia, praia do Uma, 13/IV/1994, E.A. Anunciação \& I. Cordeiro 484 (RB); Pedregulho, Parque Estadual das Furnas do Bom Jesus, em capoeirinha, brejo das nascentes, próximo da casa do núcleo de Santa Luzia, 23/I/1993, J.R. Guillaumon \& I.H.D. Castello-Branco 16066 (RB); Pindorama, Estação Ecológica de Pindorama, 09/VI/1994, R. Pilati 443 (RB); São José do Rio Preto, subdistrito de Talhado, sítios Nossa Senhora Aparecida e São Sebastião, 30/V/2009, I.M. Silva 87 (RB); São Vicente, Parque Estadual XixováJapuí, praia de Paranapuã, 05/VII/2002, J.A. Pastore \& C. Moura 1172 (RB); Teodoro Sampaio, Reserva Morro do Diabo, 27/VII/1985, M.C.W. Vieira 801 (RB); Ubatuba, Horto do IAC, caminho para a trilha do fundo (escravos), 15/V/2007, C.F. Nardim, F.R.G. Amaral, L.C. Bernacci, J.L. Silva, L.L. Haber \& M.A.R. Vieira 78 (RB); Vera Cruz, Escola Agrícola Estadual, mata ciliar degradada, 18/VIII/1998, R.B. Torres, J.C. Sales et al. 555 (RB).

\section{Piper caldense C. DC.}

BRAZIL. BAHIA: Itapebí, Lombardia, 07/XI/1967, R.S. Pinheiro \& T.S. Santos 358 (RB). ESPÍRITO SANTO: Aracruz, Barra do Riacho, 15/ $\mathrm{X} / 2009$, V.B. Sarnaglia Junior 180 (RB); Sooretama, Vale do Rio Doce Forest Reserve, Gávea Rd km 8, 25/XI/2004, M.A. Jaramillo, J.E. Meirelles \& M. Nadruz 796 (RB). MINAS GERAIS: Araponga, Parque Estadual da Serra do Brigadeiro, trilha do Mundo, R. Marquete, E.F. Guimarães, L.C. Giordano, T. Carrijo, L.S. Leoni \& M. Avelar 4101 (RB); Barroso, estrada Invejosa-Severiano Resende (antiga linha férrea), 26/ VII/2003, L.C.S. Assis \& M.S. Guimarães 877 (RB); Nova Lima, mina do Tamanduá, IX/1995, L.V. Costa s/n (RB); Patos de Minas, chácara do sennhor Moacir Quintino, 12/VII/2010, J.E.Q. Faria 887 (UB); Rio Preto, serra do Funil, 20/VIII/2004, C.N. Matozinhos, O.J.B. Neto, B.F. Mello, F.R.G. Salimena \& P.H. Nobre 3 (RB); Viçosa, Reserva Florestal Paraíso, 08/VII/1997, S.A.M. Alves 38 (VIC); idem, $20 \mathrm{~m}$ antes do final da trilha principal, 15/VIII/1997, S.A.M. Alves 40 (RB). RIO DE JANEIRO: Cantagalo, conglomerado 177-3-1-64-R, 17/XII/2013, L.B. Pimentel, A.S.C. Junqueira, M. Ramos \& R. Giovanetti-Alves s/n (RB); Nova Friburgo, Macaé de Cima, fazenda Ouro Verde, 18/VII/1993, C.M. Vieira \& L.C. Gurken 314 (RB); idem, sítio Hum Baccus, 13/IX/ 1990, C.M.B. Correira, L. Maltone, E.F. Guimarães \& J. Caruzo 241 (RB); idem, matas de Theodoro de Oliveira, 09/VIII/1989, L.C. Fogaça
\& A. Amorim 47 (RB); Petrópolis, Araras, Vivenda da Cachoeira, 10/ VIII/1980, V.F. Ferreira 1309 (RB); Serra dos Órgãos, parque, 30/VIII/ 1964, G. Pabst, G. Hatschbach \& E. Pereira 9134 (RB); Teresópolis, Granja Comary, 26/VIII/2002, R. Marquete, N. Marquete, L.C. Giordano, M.C. Valente \& J.C. Silva 3381 (RB). SÃO PAULO: Garulhos, Parque Estadual da Cantareira, núcleo Cabuçú, trilha da Cachoeira, 11/ VIII/2005, F.A.R.D.P. Arzolla, G.C.R. de Paula, F.E.S.P. Vilela e J.R. Santos 918 (RB); Mogi das Cruzes, serra do Mar, 16/IX/1983, M. Kirizawa, A.V.G. Sousa, N.N. Duque \& M.R. Silva 1058 (RB); Paranapiacaba, Estação Biológica, 28/VIII/1983, A. Custódio Filho \& C.B. Toledo 1399 (RB); São Paulo, Reserva Biológica do Parque Estadual das Fontes do Ipiranga, 24/X/1979, M. Kirizawa 503 (RB); idem, 24/X/1979, M. Kirizawa 505 (RB); Tapiraí, 12 K m de Tapiraí em direção a Juquiá, cachoeira do Chá, 09/IX/1994, M.R. Gorenstein, C.D. Sanches, E.B. Bastos, J.R.R. Hoffmann \& V.F. Pereira 41 (RB).

\section{Piper cernuum Vell.}

BRAZIL. BAHIA: Lençóis, Chapadinha, meio da mata do grotão, fendas da serra do Brejão, 25/IV/1995, M.C. Ferreira, A. Pereira, J. Costa \& E. Melo 1805 (RB); idem, na mata do grotão, 23/II/2003, A. Rapini \& P. Fiaschi 1024 (RB). ESPÍRITO SANTO: Marechal Floriano, sítio das Pacas, s/d, J. Luber s/n (RB). MINAS GERAIS: Araponga, serra de Araponga, fazenda Neblina, 01/II/1992, L.S. Leoni s/n (RB); Lima Duarte, Parque Estadual do Ibitipoca, 23/III/1988, P.M. Andrade \& M.A. Drumond 1132 (RB). RIO DE JANEIRO: Rio de Janeiro, Jardim Botânico, 08/V/1968, E.F. Guimarães \& C.B. Abreu 168 (RB).

\section{Piper chimonanthifolium Kunth}

BRAZIL. MINAS GERAIS: Viçosa, Estação de Pesquisa, Treinamento e Educação Ambiental Mata do Paraíso, 23/IX/2014, A. Valentin-Silva 81 (BOTU). RIO DE JANEIRO: Itatiaia, estrada Maromba, Km 2,5, 06/ X/1945, A.B. Pereira \& Walter 95 (RB); Teresópolis, Pimenteiras, 05/ IX/1996, E.F. Guimarães et al. 1609/09 (RB); idem, cascata perto do ponto final de ônibus, 17/X/1989, E.F. Guimarães 142 (RB); idem, rodovia Rio/Mendon, 09/XII/1987, E.F. Guimarães \& L. Mautone 19 (RB). SÃO PAULO: Biritiba Mirim, Estação Biológica de Boréia, 29/IX/ 1983, A. Custódio Filho 1572 (UB); Boa Esperança do Sul, fazenda Itaquerê, 07/VII/1964, J.C. Gomes Jr. 2059 (UB).

\section{References}

Barrett, S.C.H., Hough, J., 2013. Sexual dimorphism in flowering plants. J. Exp. Bot. 64, $67-82$.

Charlesworth, D., 1984. Androdioecy and the evolution of dioecy. Biol. J. Linn. Soc. 23, 333-348.

Eckhart, V.M., 1999. Sexual dimorphism in flowers and inflorescences. In: Geber, M.A., Dawson, T.E., Delph, L.F. (Eds.), Gender and Sexual Dimorphism in Flowering Plants. Springer-Verlag, Berlin, pp. 123-148.

Figueiredo, R.A., 1997. Fenologia e ecologia da polinização de espécies de Piperaceae em mata semidecídua do sudeste brasileiro. Universidade Estadual de Campinas Thesis.

Figueiredo, R.A., Sazima, M., 2000. Pollination biology of Piperaceae species in southeastern Brazil. Ann. Bot. 85, 455-460.

Guimarães, E.F., Carvalho-Silva, M., Monteiro, D., Medeiros, E.S., Queiroz, G.A., 2015. Piperaceae. (accessed 20.11.15). http://floradobrasil.jbrj.gov.br/jabot/ floradobrasil/FB190.

Jaramillo, M.A., Manos, P.S., 2001. Phylogeny and patterns of floral diversity in the genus Piper (Piperaceae). Am. J. Bot. 88, 706-716.

Jaramillo, M., Callejas, R., Davidson, C., Smith, J.F., Stevens, A.C., Tepe, E., 2008. A phylogeny of the tropical genus Piper using ITS and the chloroplast intron psbJ-petA. Syst. Bot. 33, 647-660.

Johansen, D.A., 1940. Plant Microtechnique. McGraw Hill, New York.

Kearns, C.A., Inouye, D.W., 1993. Techniques for Pollination Biologists. University Press of Colorado, Niwot.

Lei, L.G., Liang, H.X., 1998. Floral development of dioecious species and trends of floral evolution in Piper sensu lato. Bot. J. Linn. Soc. 127, 225-237.

Liston, A., Rieseberg, L.H., Elias, T.S., 1990. Functional androdioecy in the flowering plant Datisca glomerata. Nature 343, 641-642.

Mayer, S.S., Charlesworth, D., 1991. Cryptic dioecy in flowering plants. Trends Ecol. Evol. 6, 320-325.

Muenchow, G.E., 1998. Subandrodioecy and male fitness in Sagittaria lancifolia subsp. lancifolia (Alismataceae). Am. J. Bot. (85), 513-520.

O'Brien, S.P., 1994. Andromonoecy and fruit set in Leptospermum myrsinoides and $L$. continentale (Myrtaceae). Aust. J. Bot. 42, 751-762. 
Pannell, J.R., 2002. The evolution and maintenance of androdioecy. Annu. Rev. Ecol. Evol. Syst. 33, 397-425.

Primack, R.B., Lloyd, D.G., 1980. Andromonoecy in the New Zealand montane shrub manuka, Leptospermum scoparium (Myrtaceae). Am. J. Bot. 67, 361-368.

Quijano-Abril, M.A., Callejas-Posada, R., Miranda-Esquivel, D.R., 2006. Areas of endemism and distribution patterns for Neotropical Piper species (Piperaceae). J. Biogeogr. 33, 1266-1278.

R Core Team, 2016. R: A Language and Environment for Statistical Computing. (accessed 10.08.16). https://www.R-project.org/.

Radford, A.E., Dickison, W.C., Massey, J.R., Bell, C.R., 1974. Vascular Plant Systematics. Harper and Row, New York.

Robards, A.W., 1978. An introduction to techniques for scanning electron microscopy of plant cells. In: Hall, J.L. (Ed.), Electron Microscopy and Cytochemistry of Plant Cells. Elsevier, New York, pp. 343-403.

Roulston, T., 2005. Pollen as a reward. In: Dafni, A., Kevan, P.G., Husband, B.C. (Eds.), Practical Pollination Biology. Enviroquest. Cambridge, pp. 236-241.

Sakai, A.K., Weller, S.G., 1999. Gender and sexual dimorphism in flowering plants: a review of terminology, biogeographic patterns, ecological correlates, and phylogenetic approaches. In: Geber, M.A., Dawson, T.E., Delph, L.F. (Eds.), Gender and Sexual Dimorphism in Flowering Plants. Springer-Verlag, Berlin, pp. 1-31.

Smith, J.F., Stevens, A.C., Tepe, E.J., Davidson, C., 2008. Placing the origin of two species-rich genera in the late cretaceous with later species divergence in the tertiary: a phylogenetic, biogeography and molecular dating analysis Piper and Peperomia (Piperaceae). Plant Syst. Evol. 275, 9-30.

Tucker, S.C., 1982. Inflorescence and flower development in the Piperaceae. III. Floral ontogeny of Piper. Am. J. Bot. 69, 1389-1401.

Valentin-Silva, A., 2017. Fenologia e biologia reprodutiva de espécies de Piper

(Piperaceae) em floresta estacional semidecídua: aspectos ecológicos e filogenéticos. Universidade Estadual Paulista Thesis.

Valentin-Silva, A., Vieira, M.F., 2015. Phenology of two co-occurring Piper (Piperaceae) species in Brazil. Aust. J. Bot. 63, 581-589.

Valentin-Silva, A., Batalha, M.A., Guimarães, E., 2018. Dynamics of pollen release and stigmatic exposure in Neotropical Piper species: a possible pattern for the genus. Int. J. Plant Sci. 179, 287-295.

Veloso, H.P., Rangel Filho, A.L.R., Lima, J.C.A., 1991. Classificação da vegetação brasileira, adaptada a um sistema universal. IBGE, Rio de Janeiro.

Wanke, S., Jaramillo, M.A., Borsch, T., Samain, M.S., Quandt, D., Neinhuis, C., 2007. Evolution of Piperales - matK gene and trnK intron sequence data reveal lineage specific resolution contrast. Mol. Phylogenet. Evol. 42, 477-497.

Webb, C.J., 1999. Empirical studies: evolution and maintenance of dimorphic breeding systems. In: Geber, M.A., Dawson, T.E., Delph, L.F. (Eds.), Gender and Sexual Dimorphism in Flowering Plants. Springer-Verlag, Berlin, pp. 61-95.

Yampolsky, C., Yampolsky, H., 1922. Distribution of sex forms in the phanerogamic flora. Bibl. Genet. 3, 1-62.

Yuncker, T.G., 1972. The Piperaceae of Brazil I: Piper group I, II, III, IV. Hoehnea 2 19-366.

Yuncker, T.G., 1973. The Piperaceae of Brazil II: Piper group V; Ottonia; Pothomorphe; Sarcorhachis. Hoehnea 3, 29-284.

Zhou, X.J., Ma, L., Liu, W.Z., 2016. Functional androdioecy in the rare endemic tree Tapiscia sinensis. Bot. J. Linn. Soc. 180, 504-514. 